\title{
A 50-year analysis of hydrological trends and processes in a Mediterranean catchment
}

\author{
Nathalie Folton, Eric Martin, Patrick Arnaud, Pierre L'Hermite, and Mathieu Tolsa \\ Irstea, Aix Marseille Univ, RECOVER, 3275 Route de Cézanne, CS 40061, 13182 Aix-en-Provence, France
}

Correspondence: Nathalie Folton (nathalie.folton@irstea.fr)

Received: 22 October 2018 - Discussion started: 29 October 2018

Accepted: 13 May 2019 - Published: 25 June 2019

\begin{abstract}
The Réal Collobrier hydrological observatory in south-eastern France, managed by Irstea since 1966, constitutes a benchmark site for regional hydro-climatology. Because of the dense network of stream gauges and rain gauges available, this site provides a unique opportunity to evaluate long-term hydro-meteorological Mediterranean trends. The main catchment $\left(70 \mathrm{~km}^{2}\right)$ and its sub-catchments are located in the Massif des Maures of south-eastern France, close to the Mediterranean coast. The vegetation is composed of forest mainly calcified on crystalline soils (maquis of heath, corkoak, maritime pine and chestnut). Direct human influence has been negligible over the past 50 years. The land use and land cover has remained almost unchanged, with the notable exception of a wildfire in 1990 that impacted a small subcatchment. Therefore changes in the hydrological response of the catchments are caused by changes in climate and/or physical conditions. This study investigates changes in observational data using up to 50-year daily series of precipitation and streamflow. The analysis used several climate indices describing distinct modes of variability, at inter-annual and seasonal timescales. Trends were assessed by the MannKendall method. The analysis also used hydrological indices describing drought events based on daily data for a description of low flows, in particular in terms of timing and severity. The analysis shows that there is a marked tendency towards a decrease in the water resources of the Réal Collobrier catchment in response to climate trends, with a consistent increase in drought severity and duration. But the changes are variable among the sub-catchments.
\end{abstract}

\section{Introduction}

The Mediterranean climate is known for its warm, dry summers and high-precipitation events, mainly occurring during autumn (Drobinski et al., 2014). Hence climate variability is higher in this area than in neighbouring regions. In the context of the ongoing climate change, several studies have attempted to detect trends in the hydrological variables. Chaouche et al. (2010) studied trends in the western part of the Mediterranean region over the 1970-2006 period. They mainly found an annual increase in temperature and potential evapotranspiration (PET), while no significant trends were detected for annual precipitation. Several studies focused on the evolution of precipitation extremes over the region (Tramblay et al., 2013; Ribes et al., 2018; Pujol et al., 2007). They concluded that there had been a significant intensification in extreme precipitation events at the regional scale, while at the local scale the evolution was highly variable. Hertig and Tramblay (2017) found a widespread increase in meteorological droughts in the whole Mediterranean basin for the period 1970-2000. Lespinas et al. (2010) suggested that groundwater evolution has a significant impact on drought trends and dynamics in the region.

In the 1960s, the French Ministry of Agriculture decided to create several experimental catchments in order to improve our knowledge of the hydrological cycle and its impact on agriculture under various French climates. One of these watersheds is the Réal Collobrier Catchment, situated in south-eastern France, $50 \mathrm{~km}$ from the sea, at elevations ranging from 70 to $780 \mathrm{~m}$ a.s.l. (Lavabre, 1989; Folton et al., 2012). The whole watershed (area $70 \mathrm{~km}^{2}$ ) and several subwatersheds have now been monitored for 50 years, including precipitation and discharge. This exceptional dataset has been recently re-checked and validated. 
The objectives of this paper are to document hydrological trends over this catchment, including extreme precipitation and droughts. The study also aims to better understand drought mechanisms through precipitation and flow measurements associated with hydrological modelling. First, the physical characteristics of the catchment, the associated dataset and the methods and model used are described. Second, annual and monthly precipitation trends are analysed. Finally, we discuss the 50-year evolution of the main hydrological characteristics and changes in the hydrological processes occurring in the watershed, in relation to the larger Mediterranean context.

\section{Catchment description and data}

\subsection{General description}

The Réal Collobrier research catchment is located in southeastern France, at the western end of the Maures mountain range on the Mediterranean coast. Its surface is $70 \mathrm{~km}^{2}$, with a maximum length of $16 \mathrm{~km}$ and a maximum width of $9.6 \mathrm{~km}$ (Fig. 1). Its elevation varies from 70 (at the outlet at the western end) to $780 \mathrm{~m}$ (north-east of the catchment). The average elevation is $335 \mathrm{~m}$.

The Réal Collobrier watershed is representative of the geological formations of the crystalline Provence of the Maures, composed of metamorphic and granitic massifs. The main hydrographic axis is aligned with the large Collobrières east-west fault and the tributaries of the Réal Collobrier are oriented NW-SE, perpendicular to the direction of the rocks. We observe different metamorphic facies, from west to east: micaschists, amphibolites, phyllads and gneiss (Martin, 1972).

The terrains of the crystalline basement of the Maures are characterized by an alteration of the basement with a coarse and thin texture (1-2 m). Permeability is generally quite poor and groundwater supplies are extremely limited. Aquifers in this crystalline zone supply little to the Réal Collobrier tributaries that dry up rapidly in summer.

Forest cover largely dominates the hillside areas. The upstream sub-catchments therefore have a densely wooded vegetation cover composed of most of the calcifuge Mediterranean species: cork oaks, holm oaks, heather, arbutus trees, cistus and chestnut plantations. Scrubland occupies land with a thin soil cover. Soil thickness ranges from thin skeletal ranker soil in the small Rimbaud watershed (to the east) to alluvial soil several metres thick in the low valleys. The urbanization of the catchment is low, with the exception of the small town of Collobrières (1200 inhabitants in the 1960s, 2000 inhabitants today). The downstream part of the watershed (downstream of Collobrières) is occupied by a large agricultural plain planted mainly with non-irrigated vineyards. Because of the weak anthropic influence, the hydrological cycle of the watershed is very close to the natural one.
The catchment is characterized by a typical Mediterranean climate with dry summers and high precipitation events, mainly during autumn (September to December). Due to the orography, the mean precipitation $\left(1055 \mathrm{~mm} \mathrm{yr}^{-1}\right)$ is higher than in the surrounding areas. Table 1 summarizes the main characteristics of the catchment and sub-catchments monitored.

\subsection{Meteorological and hydrological data}

The analyses were conducted at the scale of the whole catchment (outlet: Pont de Fer) and five sub-catchments. A total of 6 hydrological stations and 14 rain gauges were used. Available data were calculated at a daily time step from January 1968 to December 2017 . The equipment was slightly modified over the period analysed in order to adapt to the evolution of metrological material. Precipitation was measured by tipping-bucket rain gauges uniformly distributed over the entire catchment; their spatial distribution is shown in Fig. 1. The data were recorded on stable sites in terms of measurement protocols and observation conditions (approved equipment, no displacement of rain gauges and preservation of site conditions). To satisfy this condition, two rain gauges were removed from the study (out of 16 measured rainfall sites, only 14 were used). The time series were subject to prior descriptive statistical reviews and contain less than $20 \%$ missing data. The trend tests were applied on 14 rain gauges, but the results of the trend tests were very different from one rain gauge to another. According to Cantat (2004), many direct and indirect rainfall factors induce a certain heterogeneity in rainfall series. He concluded that the spatial and temporal fragmentation of the rainfall series affects the identification of long-term rainfall trends, and that series with too many gaps make reconstruction and analysis difficult. In order to have an overall idea of the rainfall trends in the Réal Collobrier catchment, the tests were therefore applied to the catchment averaged rainfall, at the risk of concealing the trend (if it exists) in the different rainfall signals. According to Louvet et al. (2011) and given the strong density of our rain gauge network, the interpolation method has no impact on the trend diagnostics. Spatial interpolation of the rainfall over the catchment was done with the inverse distance weighted method (IDW), widely used in rainfall interpolation (Yang et al., 2015). IDW is based on the function of the inverse distances and assumes that each input point has a local influence that diminishes with distance (Eckstein, 1989).

The catchment runoffs were computed from water depth measurements with hydrometric equipment (a float). The gauging sections were stable over the period, as they were built in a calibrated structure in order to not be subject to change (erosion, seasonal variations in the growth of aquatic plants). The gauging sections were equipped with triangular or rectangular sharp-crested weirs to reduce uncertainties in the relation of river level and river flow. 


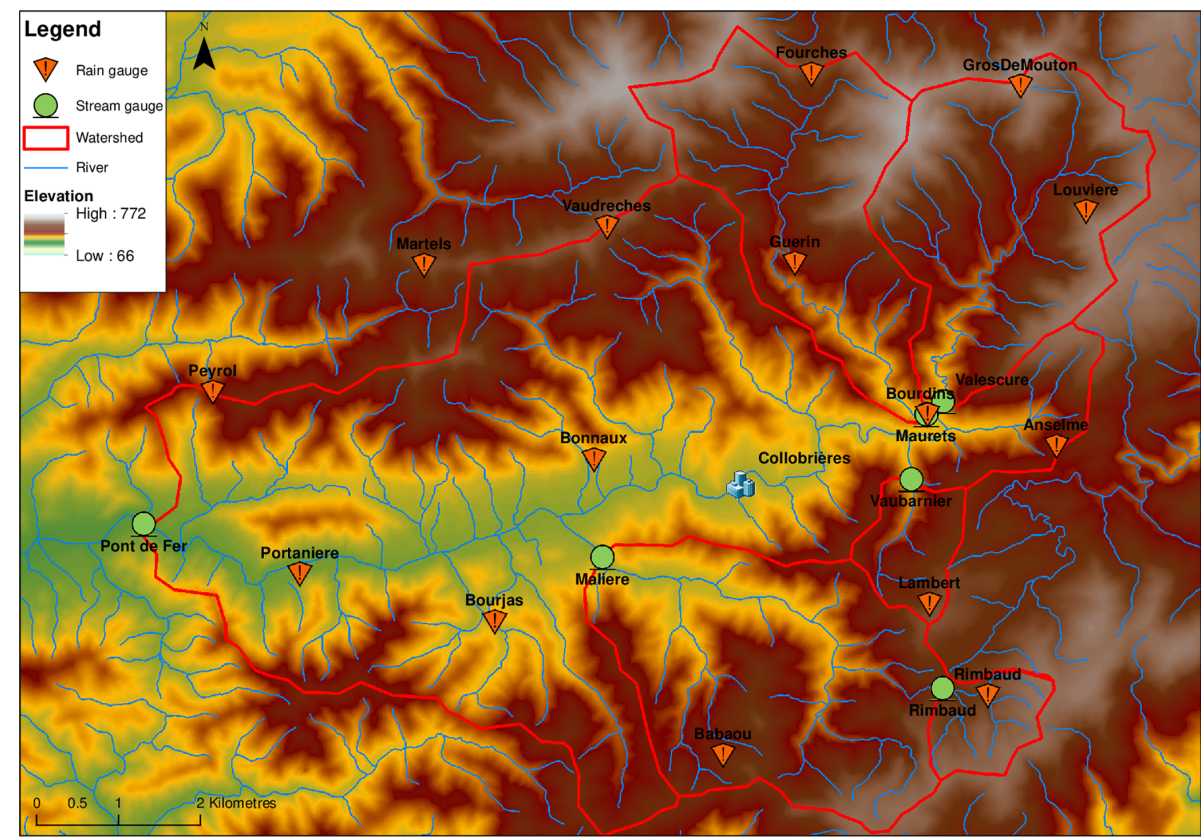

Figure 1. Map of the whole catchment and the five sub-catchments.

\section{Methods}

This section describes the main indices used to characterize the hydrologic regime of the catchment. These indices are time series on which statistical tests were applied to determine trends.

\subsection{Rainfall indices}

We used hydroclimatic indices recommended by the ETCCDI/CRD Climate Change Indices (Peterson et al., 2001), derived from daily rainfall. These indices can be separated into four categories: threshold indices, duration indices, absolute indices and standardized indices. Table 2 provides the detailed description of these indices. In this table " $R$ " represents the daily rainfall and " $x$ " is a rainfall threshold. A day is defined as "dry" ("wet") if the daily precipitation is below (above) a threshold. For the driest days, the $2 \mathrm{~mm}$ threshold was used since, for water resources, small amounts of rainfall do not reduce water stress because it is immediately taken up by vegetation (interception and evapotranspiration). Four additional thresholds were used $(5,10,20$ and $30 \mathrm{~mm})$ as proposed by Balme-Debionne (2004).

Besides analysis of the annual extremes, drought phenomena can be analysed at the monthly time step through the standardized precipitation index (SPI) (inter alia McKee et al., 1993; Hayes et al., 2011; Lee et al., 2017; Javanmard et al., 2017). The SPI is calculated from a continuous daily precipitation time series accumulated over $n$ sliding months ( $n=1,3,6,12,24$ months). These $n$ months represent different timescales that may correspond to periods of rainfall deficit, leading to an impact on the different compartments of the water cycle. The $n$-month rainfall time series are fitted to a Gamma law that is usually used to fit accumulated precipitation data (Guttman, 1999; Stagge et al., 2015; Yacoub and Tayfur, 2017), but we checked the goodness of fit of the gamma law for each daily precipitation time series accumulated over $n$ sliding months. This fitting is done independently for each month. Frequencies are estimated using the fitted Gamma law and transformed to a reduced and centred normal variable. This transformation yields a symmetric variable representing the $n$-month rainfall and called SPI. Positive SPI values indicate precipitation above the median and negative values indicate precipitation below the median.

\subsection{Hydrological indices}

The stationarity analysis of hydrological regimes investigated the evolution of indices calculated from daily discharges, on the six catchments of the Réal Collobrier. These indices (see Table 3) can be divided into five categories: absolute, threshold, duration, low flows and standardized indices.

\subsubsection{Absolute indices}

The absolute indices used were the annual maximum flow, the mean annual flows and the mean monthly flows. These indices were complemented by other indices to characterize the various aspects of hydrological drought events based on daily discharge. 


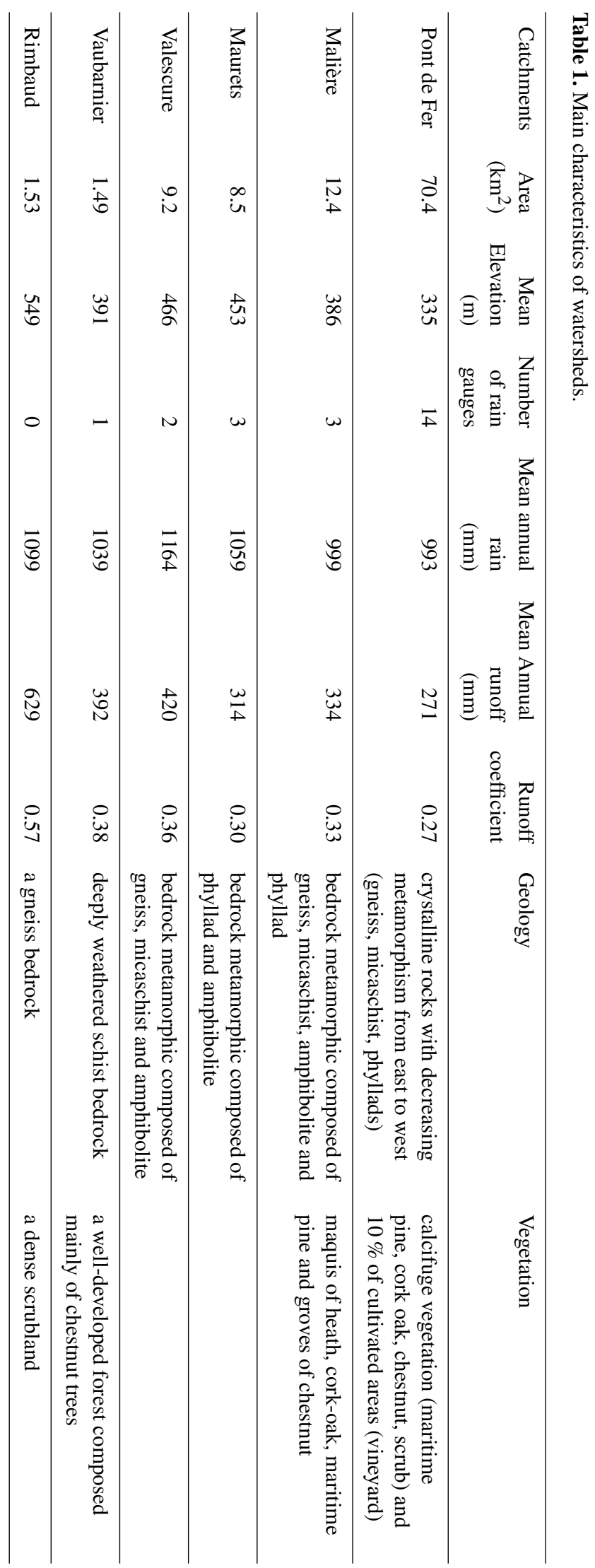

\subsubsection{Threshold and duration indices}

The characterization of a drought episode usually depends on the definition of a threshold which characterizes the drought duration, volume deficit or similar indices (Yevjevich, 1967; Smathkin and Watkins 1997; Hisdal et al., 2004). This threshold is most often derived from the flow duration curve (FDC, Tallaksen and Van Lanen, 2004), which characterizes catchment runoff variability. The flow duration curve relates the streamflow magnitude (vertical axis) with the exceedance frequency (horizontal axis). The classical method (Beard, 1943) uses the entire series available to build a single curve. However, Vogel and Fennessey (1995a, b) proposed to estimate a median flow duration curve based on yearly curves calculated from the observed series. This method is less sensitive to extreme events and is considered more representative of the mean catchment behaviour. The choice of the threshold (a percentile of the curve) results from a compromise that allows the characterization of the low-flow severity. Then, periods with values below the defined threshold are defined as periods of hydrological drought. The most commonly used percentiles range from 0.7 th percentile $(\mathrm{Q} 70)$ to 0.9th percentile (Q90) (Gregor, 2013). In the present study, we used the 0.8-percentile (Q80), a value used in many drought studies (Laaha et al., 2017).

The low-flow indices were derived using this threshold. Figure 2 shows the methodology for evaluating the hydrological drought indices. These indices are as follows:

- The annual volume deficit relative to the low-flow threshold (called "DEF") (Giuntoli et al., 2013) is the volume between the threshold and the flows below the threshold.

- The number of days per year where the flow is below the threshold (low-flow duration called "LFD").

- The seasonality of low flow was studied using the concept of the centre of mass introduced by Stewart et al. (2005). The $x \%$ centre of mass is defined as the date on which $x \%$ of the annual volume deficit flows is observed. The $10 \%, 50 \%$ and $90 \%$ centre of mass are used to define the beginning (Start), the centre (Centre) and the end (End) of the low-flow period for each year.

\subsubsection{Low-flow indices}

The last index to characterize low-flow is the base flow index (BFI). We used this index to characterize the stationarity of the low-flow sensitivity of the watersheds. The BFI varies between 0 and 1 . A high value of BFI reflects a high groundwater contribution to discharge, while low values are typical for catchments with a low influence of groundwater on the total discharge. It was developed in the UK by the Institute of Hydrology (1980) and represents the ratio between the base flow (BFlow) and total discharge. To calculate the 
Table 2. Precipitation indices used in this study.

\begin{tabular}{|c|c|c|c|}
\hline Type & Name & Definition & Unit \\
\hline \multirow[t]{3}{*}{ Threshold } & $\mathrm{WD}_{x}$ & Annual count of wet days, when $R>x(x=2,5,10,20$ and $30 \mathrm{~mm})$ & $\mathrm{d}$ \\
\hline & $\mathrm{INT}_{x}$ & Mean rainfall intensity during wet days, when $R>x(x=2,5,10,20$ and $30 \mathrm{~mm})$ & $\mathrm{mm} \mathrm{d}^{-1}$ \\
\hline & PRTOT $_{x}$ & Annual total precipitation from wet days when $R>x(x=2,5,10,20$ and $30 \mathrm{~mm})$ & $\mathrm{mm}$ \\
\hline \multirow[t]{3}{*}{ Duration } & $\mathrm{CWD}_{x}$ & Maximum number of consecutive wet days with $R>x(x=2,5,10,20$ and $30 \mathrm{~mm})$ & $\mathrm{d}$ \\
\hline & $\mathrm{CDD}_{x}$ & Maximum number of consecutive dry days with $R<x(x=2,5,10,20$ and $30 \mathrm{~mm})$ & $\mathrm{d}$ \\
\hline & $\operatorname{DSL}_{x}$ & Mean number of consecutive dry days with $R<x(x=2,5,10,20$ and $30 \mathrm{~mm})$ & $\mathrm{d}$ \\
\hline \multirow[t]{5}{*}{ Absolute } & R1d & Annual maximum $1 \mathrm{~d}$ precipitation time series & $\mathrm{mm}$ \\
\hline & R3d & Annual maximum $3 \mathrm{~d}$ precipitation time series & $\mathrm{mm}$ \\
\hline & R5d & Annual maximum $5 \mathrm{~d}$ precipitation time series & $\mathrm{mm}$ \\
\hline & $\mathrm{PA}$ & Annual total precipitation time series & $\mathrm{mm}$ \\
\hline & PM & Monthly total precipitation time series & $\mathrm{mm}$ \\
\hline Standardized & $\mathrm{SPI}_{n}$ & Standardized Precipitation Index calculated over $n$ months $(n=1,3,6,12,24)$ & \\
\hline
\end{tabular}

Table 3. Hydrological indices used to characterize the hydrological cycle.

\begin{tabular}{llll}
\hline Type & Name & Definition & Unit \\
\hline Absolute & AMax1d & Annual maximum 1 d streamflow & Mm \\
& QA & Annual streamflow & Mm \\
& QM & Monthly streamflow & Mm \\
\hline Threshold & DEF & Deficit volume = annual streamflow below threshold & Mm \\
\hline Duration & LFD & Low-flow duration = number of days per year where the day flow < threshold & d \\
& Start & Start date of drought duration & Day of year \\
& Centre & Centre date of drought duration & Day of year \\
& End & End date of drought duration & Day of year \\
\hline \multirow{2}{*}{ Low flows } & BFI and & Base flow index & - \\
& BFlow & Base flow & mm \\
\hline Standardized & SSI & Standardized Streamflow Index & - \\
\hline
\end{tabular}

base flow, there are number of methods available (Brodie and Hostetler, 2005). For the basic hydrological separation of the base flow from the total runoff, the most often used method is the automated time-based separation, named "local minimum method", proposed by the Institute of Hydrology (1980) and detailed by Gustard and Tallaksen (2008). This method was applied using the code developed by the European Drought Center (Hisdal et al., 2004). The technique consists in subdividing the time series into intervals of " $n$ " points that do not overlap. From these intervals, the minimum flow is extracted. The curve of base flow is calculated by linear interpolation of these inflection points. We chose a $5 \mathrm{~d}$ reference period $(n)$, which is usually used for this type of analysis. We named the indices obtained by this method BFI_L and Bflow_L. The second method uses a recursive digital filter for the separation process. The algorithm suggested by Lyne and Hollick (1979) with only one parameter was used because this filter is easy to automate and its approach has been widely used (Ladson et al., 2013). The method calculates the base flow for each interval (day $i$ ) using the flow at day $(i)$, day $(i-1)$ and one parameter (the recommended parameter value is 0.925 ; Nathan and MacMahon, 1990). We named the indices obtained by this method BFI_F and Bflow_F.

When we compare the two separation processes, the "local minimum method" (Bflow_L) has a less fine smoothing than the filter method (Bflow_F).

\subsubsection{Absolute indices}

The Standardized Streamflow Index (SSI) uses the same principle as the SPI, aggregating streamflow data over the given accumulation periods (Vincente-Serrano et al., 2012; Lorenzo-Lacruz et al., 2013). However, there is no widely adapted probability distribution to fit streamflow data in order to calculate the SSI (Barker et al., 2016). We therefore verified the goodness of fit of the gamma distribution to empirical data for the Réal Collobrier discharge series. 


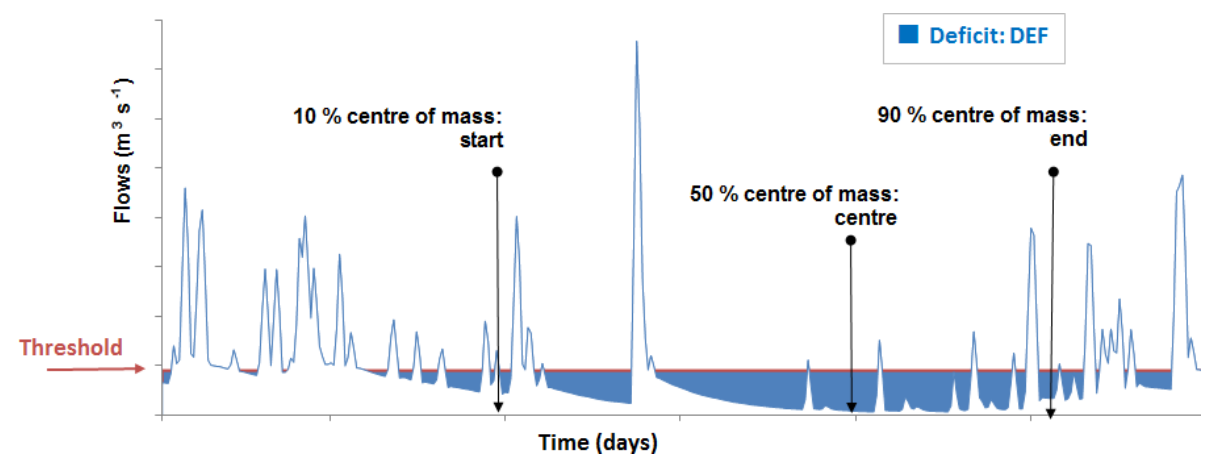

Figure 2. Definition of hydrological drought indices.

\subsection{Trend analysis methods}

Trend detection tests that indicate possible non-stationarity were applied to all indices. We used two non-parametric trend tests which require only independent data, while parametric trend tests require the assumption of independent and normally distributed data. The first-order autocorrelation coefficient of the time series was calculated for each series and a test applied to detect autocorrelations significantly different from zero (function "acf" from the R package STATS; Venables and Ripley, 2002).

\subsubsection{Mann-Kendall test and modified Mann-Kendall test}

The Mann-Kendall test (MK test) (Mann, 1945; Kendall, 1975) is a rank-based non-parametric test used to detect significant trends in climatic variables. It is widely applied to hydro-meteorological time series in different regions around the world (Douglas et al., 2000; Yue at al., 2002; Tabari et al., 2011; Jhajharia et al., 2012; Gocic and Trajkovic, 2013; De la Casa and Ovando, 2016; Gao et al., 2017). This test, based on the ranks of observations rather than their values, is not affected by the distribution of the data and it is less sensitive to outliers. The robustness of the test was validated by several comparison tests conducted by Yue and Wang (2004). The $p$ value presents the significance level to reject the null hypothesis of the Mann-Kendall test $\mathrm{HO}(\mathrm{HO}=$ no trend). In this study, predefined significance levels $\alpha=0.01, \alpha=0.05$ and $\alpha=0.1$ were used. The null hypothesis is rejected if the $p$ value is lower than the significance level chosen (Sicard, 2006). Full details related to the Mann-Kendall test can be found in the studies by Hamed (2008), Kumar et al., (2009), Gocic and Trajkovic (2013), and Jhajharia et al. (2013). The function "mk.test" from the R package TREND was used (Hipel and McLoed, 2005).

The Mann-Kendall test performs poorly when the autocorrelation is high (Yue et al., 2002; Yue and Wang, 2004; Hamed, 2008). Tied values are present in samples of annual streamflow, of the standardized precipitation and of standardized flows. To compute the MK statistic in correlated se- ries, Hamed and Rao (1998) therefore modified the MannKendall test by variance correction. This modified MK test was applied to the data series for which a significant autocorrelation was detected.

\subsubsection{Sequential version of the Mann-Kendall test statistic}

The sequential version of the Mann-Kendall test statistic (Sneyres, 1990) applied on time series detects approximate potential trend turning points in long-term series (Kumar et al., 2016). Gerstengarbe and Werner (1999) or Bisai et al. (2014) described the successive steps to be applied in order to accept or reject the null hypothesis (H0: sample under investigation shows no beginning of a new trend). To apply this test, we used the seqMK function of the PHENO R Package (Sneyres, 1990), with a $p$ value of $5 \%$ to accept the H0 hypothesis.

\subsubsection{Sen's slope estimator}

The Mann-Kendall test is associated with the calculation of Sen's slope or the Theil-Sen estimator (Theil, 1950; Sen, 1968). This method has been largely used in order to identify the slope of trend line in a hydrological time series. Sen's slope $(\beta)$ represents the median from all slopes calculated between each pair of points as follows:

$\beta=\operatorname{Median}_{1<i<j<n}\left\{\frac{x_{j}-x_{i}}{j-i}\right\}$,

with $n$ the number of data; $i$ and $j$ are indices.

The estimate of the intercept is then computed by the method recommended by Helsel and Hirsh (2002) using Sen's slope and the median of the variables (Conover, 1980). 


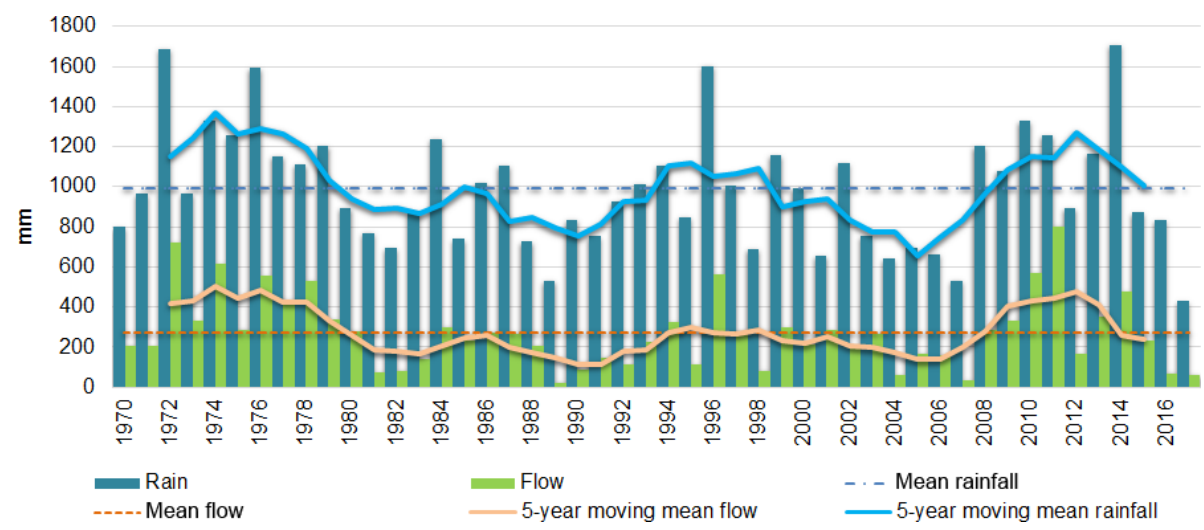

Figure 3. Annual rainfall and flow on Pont de Fer catchment.

\section{Hydrological characteristics of the catchment and sub-catchments}

\subsection{Runoff quantitative analysis}

The analysis of Table 1 and Fig. 1 allows an initial comparison between catchments. The Pont de Fer watershed is the main catchment, fed by the other sub-catchments. For the analysis we compared catchments individually or by groups: e.g. the Rimbaud and Vaubarnier catchments (two small neighbouring catchments, about $1.5 \mathrm{~km}^{2}$ ), the Maurets and Valescure catchments (two neighbouring catchments having an area of around $9 \mathrm{~km}^{2}$ ), and the Malière and Rimbaud catchments (Malière, $12 \mathrm{~km}^{2}$, receiving the flows of the Rimbaud watershed).

Figure 3 shows the interannual evolution of the mean annual rainfall and the mean annual discharge at the main outlet of the catchment (Pont de Fer). The average precipitation is $993 \mathrm{~mm} \mathrm{yr}^{-1}$ and ranges between $428 \mathrm{~mm}$ (in 2017) and $1709 \mathrm{~mm}$ (in 2014). Averaged over the 50 years, the spatial variation of the sub-catchments' rainfall is low (between 993 and $1164 \mathrm{~mm} \mathrm{yr}^{-1}$, Table 1) but can be extremely high at lower timescales. The mean annual runoff at Pont de Fer $\left(271 \mathrm{~mm} \mathrm{yr}^{-1}\right.$ ) (Fig. 3) ranges from $35 \mathrm{~mm}$ (in 1989) to $805 \mathrm{~mm}$ (in 2011). This main catchment receives the lowest catchment rainfall and returns also the lowest proportion of rain (runoff coefficient of 0.27). At sub-catchment scale, mean annual runoff ranges from 271 to $629 \mathrm{~mm}$ and the runoff coefficient (runoff / rainfall ratio) is around 0.35.

The two smaller catchments have very different behaviours. The Rimbaud catchment is characterized by a runoff coefficient of 0.57 , due to its special soil characteristics: the massive nature of the rocks (gneiss), the thinness of the surface formation and the morphometric characteristics promote a dynamic hydrological response to rainfall. There is a high contrast between this sub-catchment and the surrounding Vaubarnier sub-catchment (runoff coefficient of 0.38). The Vaubarnier sub-catchment is characterized by a strong inertia due to its geological structure that plays a dom- inant role in the runoff production. An ensemble of juxtaposed and independent aquifers with a high retention capacity plays a strictly capacitive role, a situation which favours high losses through evapotranspiration from vegetation. This catchment can be characterized by inter-annual regulations. The runoff coefficients of the other three sub-catchments (Maurets, Valescure and Malière) are equivalent, on the order of $30 \%$ to $36 \%$.

\subsection{Analysis of monthly flow dynamic}

The seasonal rainfall cycle of the catchments is typical of a Mediterranean catchment (Fig. 4). In general, for all catchments, the June-August period is very dry, with rainfall of less than $40 \mathrm{~mm} m o n t h^{-1}$ and runoff less than $10 \mathrm{~mm}$ month $^{-1}$. Rainfall increases in September, but with a very limited impact on discharge. October and November are the wettest months (around $130 \mathrm{~mm} \mathrm{month}^{-1}$ ). The wet season ranges from October to January, but high precipitation events can occur any time from September to June. The flow is not permanent and can vanish during the dry period. At the start of the hydrological year, in September, the catchments need high rainfall contributions to reinitiate the permanent flow regime. The flows are low, in autumn, despite high rainfall. The most abundant flows then occur in winter in January, with rainfall of the same order as in autumn.

If we compare the smallest catchments, the very particular hydrological behaviour of the Rimbaud sub-catchment described above is clearly marked; its bare soils (gneiss) generate the highest runoff, except in summer when it is the lowest. During this period, the Vaubarnier sub-catchment has the most advantageous restitution capacity with the highest runoff, in relation with its hydrogeological characteristics already mentioned above.

If we compare the contiguous sub-catchments of Maurets and Valescure, which have similar morphometric characteristics, the Maurets sub-catchment is in a sheltered situation and receives slightly less rain than the Valescure sub-catchment. The excess rainfall and lithological conditions determine the 


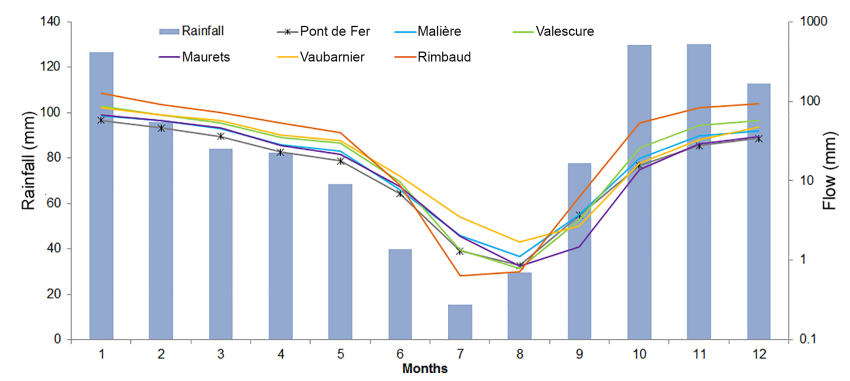

Figure 4. Mean annual cycle of rainfall at Pont de Fer from 1968 to 2017 (histogram) and mean annual cycle of runoff for the six catchments for the same period (curves).

differences in hydrological behaviour between the two catchments. Valescure has a higher flow linked to higher rainfall and its lithology is more suitable for flow (gneiss and micaschist). The Maurets sub-catchment composed of phyllads upstream promotes a slightly more effective low-water support than the Valescure sub-catchment.

The Malière sub-catchment of $12.3 \mathrm{~km}^{2}$ includes in its upper part a lithology that is more suitable for flow (gneiss and micaschist), like the Valescure sub-catchment, but its rainfall is lower. Pont de Fer is the main catchment.

\section{Trends}

\subsection{Rainfall trends}

\subsubsection{Absolute indices}

At the annual scale, the precipitation trend (Sen's estimator) is $-5.4 \mathrm{~mm} \mathrm{yr}^{-1}$ and is not significant according to the Mann-Kendall test. At the monthly scale, the only significant value $(P<0.1)$ is March: $-1.3 \mathrm{~mm}^{\text {month }}{ }^{-1}$. Among the other months, eight show a decreasing trend while July, October and November indicate an increasing trend.

For annual maximum $n$-day precipitation, no trend was detected. This is certainly due to the difficulty of finding trends in extreme values.

\subsubsection{Threshold and duration indices}

The indices based on daily precipitation above and below the thresholds show a drying trend over the whole 1968-2017 period (Table 4). The wet days' indices (WDx) showed a significant decreasing trend for the thresholds ranging from 2 to $20 \mathrm{~mm}$. The results of the sequential Mann-Kendall test statistic (not shown) showed a breakpoint in 1980. Before this date the indices were stable and afterwards a significant decrease until 2007 was detected. In the case of the dry spell length (DSLx), a significant increasing trend was observed for the 5 and $20 \mathrm{~mm}$ thresholds. Before 1975, the index decreased, then a meaningful long-term trend can be identified until 2007, after which it decreased again. No significant

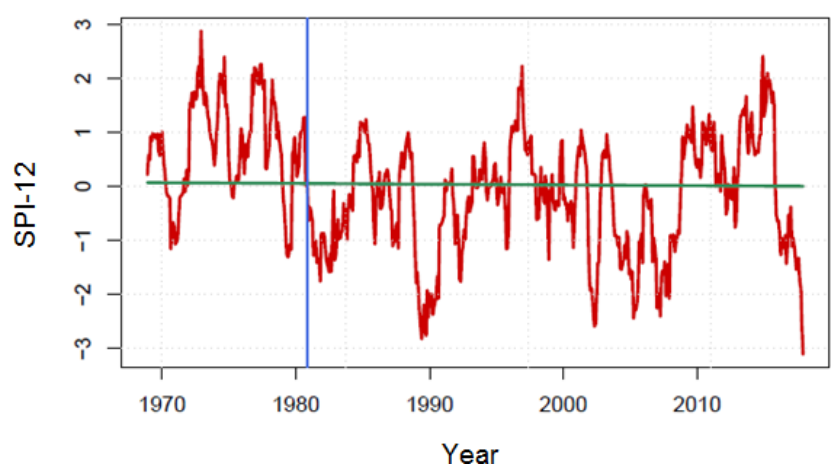

Figure 5. SPI-12 at Pont de Fer.

trend could be identified from the other indices characterizing the duration or the intensity of rainfall (CWD or CDD). These indices appear to be too sensitive to sampling, since a rainstorm can disturb the calculation of consecutive dry days.

\subsubsection{Standardized indices}

The Mann-Kendall test and Sen's slope estimator for 1, 3, 6, 12 and 24 monthly SPI showed significant trends only for SPI-1 and SPI-3. For example, for SPI-1 the slope is -0.0005 per year, which means that SPI- 1 decreased by 0.25 over the observed period. This trend can be attributed to a change in the monthly rainfall variability related to the decrease in rainfall during March. On the other hand, the interannual variability does not seem to be significantly disturbed because the trends in SPI-6 to SPI-24 are not significant. However, for these long durations (12 and 24 months), the sequential Mann-Kendall test exhibits a continuously decreasing trend from 1980 to 2007 with a detectable change point: 1980 . Over this period, the values of SPI-12 (Fig. 5) show two major dry periods centred on 1990 and during the period 20042007. In addition, the lowest values of SPI-12, located in 1989 and 2017, are close to -3 , characterizing a severe dry period.

\subsection{Hydrological trends}

Yearly, seasonal and low flows of Réal Collobrier's catchments were analysed with the hydrological indices defined in Sect. 3.2.

\subsubsection{Absolute indices}

We investigated the existence of trends in mean annual, maximum annual (Amax1d) and mean monthly flows. For annual mean flows, all the detected trends were negative (ranging from $-2.466 \mathrm{~mm} \mathrm{yr}^{-1}$ at Pont de Fer to $-6.357 \mathrm{~mm} \mathrm{yr}^{-1}$ at Rimbaud) but not significant except for the Mauret catchment, with a significant trend of $-4.866 \mathrm{~mm} \mathrm{yr}^{-1}$ (Table 5). Table 5 also indicates decreasing, albeit not significant, trends in maximum annual flow. 
Table 4. Sen's slope of linear trends and the value of the Mann-Kendall test in duration and threshold indices of rainfall. Symbols represent significance level $P$ according to the Mann-Kendall test.

\begin{tabular}{|c|c|c|c|c|c|c|c|c|c|c|c|}
\hline \multirow[t]{2}{*}{ Types } & \multirow[t]{2}{*}{ Indices } & \multicolumn{2}{|c|}{ Threshold } & \multicolumn{2}{|c|}{ Threshold } & \multicolumn{2}{|c|}{ Threshold } & \multicolumn{2}{|c|}{ Threshold } & \multicolumn{2}{|c|}{ Threshold } \\
\hline & & \multicolumn{2}{|c|}{$2 \mathrm{~mm}$} & \multicolumn{2}{|c|}{$5 \mathrm{~mm}$} & \multicolumn{2}{|c|}{$10 \mathrm{~mm}$} & \multicolumn{2}{|c|}{$20 \mathrm{~mm}$} & \multicolumn{2}{|c|}{$30 \mathrm{~mm}$} \\
\hline \multirow[t]{3}{*}{ Threshold } & WDx & -0.333 & $* *$ & -0.250 & $* *$ & -0.161 & $* * *$ & -0.118 & $* *$ & -0.059 & - \\
\hline & INTx & -0.013 & - & -0.004 & - & 0.010 & - & 0.020 & - & 0.003 & - \\
\hline & PRTOTx & -5.412 & - & -5.274 & - & -4.521 & - & -3.850 & - & -2.784 & - \\
\hline \multirow[t]{3}{*}{ Duration } & CWDx & 0.000 & - & 0.000 & - & 0.000 & - & 0.000 & - & 0.000 & - \\
\hline & CDDx & -0.029 & - & 0.000 & - & -0.094 & - & 0.167 & - & -0.050 & - \\
\hline & DSLx & 0.032 & - & 0.068 & $* *$ & 0.073 & - & 0.152 & $* * *$ & 0.136 & - \\
\hline
\end{tabular}

${ }^{* *} P<0.05{ }^{* * *} P<0.1$. A dash $(-)$ means not significant.

At the seasonal scale, all the catchments presented significant negative trends for spring flows, especially for March and April. Moreover, only the Vaubarnier sub-catchment presented a significant decreasing trend in September and October.

There are differences, especially in the autumn months (November-December). The flow decreases in at least one of these months in the two catchments with slow hydrological processes (Vaubarnier and Maurets), while in the other catchments the flows increase. However, the trends are not significant. The null values of Sen's slope observed for the summer months (July-August) are influenced by the null flows in these months, except for the Vaubarnier catchment which has the highest runoff in summer.

\subsubsection{Low-flow and duration indices}

Table 6 shows the indices computed in order to detect trends in low flows and their duration. The following appear to be true:

- The low-flow period starts earlier for all watersheds, except the Malière sub-catchment, and this change is significant only in the Rimbaud sub-catchment. The amplitude of this change is on average $19 \mathrm{~d}$ over the 50 -year period observed for this catchment. This is particularly the case for the Rimbaud catchment, whose functioning is strongly linked to rainfall. The decrease in spring rainfall then leads to earlier low flows.

- The end of the low-flow period occurs later for all catchments; this shift is significant for Pont de Fer and Valescure catchments. For five of the six catchments, the dry period starts earlier and finishes later in the year. Overall, the low-flow period is longer and the low-water period is centred on a later date, representing a shift of 1 to 3 weeks over the observation period.

- Trends in durations are significant for the two smaller catchments. The volume deficit of drought (DEF) increases for all catchments and significantly only for
Vaubarnier. The Vaubarnier sub-watershed is the most strongly affected in terms of low-flow deficit, followed by the Maurets sub-watershed. These are the two catchments that strongly support the low-flow period (high values of the mean BFI) and are therefore more sensitive during low-flow periods. Catchments such as Rimbaud, with null flows in summer, are less impacted in terms of deficit although their period of low water increases, because of low retention capacity. Although the BFI values are calculated using two different methods, their trend analysis shows identical results (Table 6). The base flow (BFlow) shows a downwards trend for all catchments, and is significant for Pont de Fer and Rimbaud catchments.

- The low values of mean BFI reflect a low storage capacity (e.g. 0.21 for the Rimbaud sub-catchment) and higher values reflect a greater storage capacity ( 0.367 for the Vaubarnier sub-catchment). The results are mixed, however: a decreasing trend is observed for three catchments and an increasing trend for the other three. Only one positive trend is significant (Malière).

Overall, the results show an increase in volume deficits associated with an extension of the low-flow period. The catchments with the smallest area appear to be the most significantly affected.

\subsubsection{Standardized indices}

The results of the Mann-Kendall test and Sen's slope estimation for 1, 3, 6, 9, 12 and 24 monthly SFI over the whole period are presented in Table 7.

The Rimbaud and Vaubarnier sub-catchments show a significant decreasing trend for all timescales, except for SFI24 for Vaubarnier. Again, the trends are significant only for the small catchments. In the other catchments, while the trends are also decreasing, they are not significant, except for Pont de Fer for the 1- and 3-month timescales. Significant 1month deficits (SFI-1) are doubtless related to the March rainfall deficit observed, which also translates into a deficit 
Table 5. Sen's slope of linear trends and the value of the Mann-Kendall test in monthly $\left(\mathrm{mm} \mathrm{month}^{-1}\right)$ and annual streamflow (mm yr $\left.{ }^{-1}\right)$ and Amax 1d index. Symbols represent significance level $P$ according to the Mann-Kendall test.

\begin{tabular}{lrr|rr|r|r|r|r|rr|r|r}
\hline & \multicolumn{2}{c}{ Pont de Fer } & \multicolumn{2}{|c|}{ Malière } & \multicolumn{2}{|c|}{ Valescure } & \multicolumn{2}{|c|}{ Maurets } & \multicolumn{2}{|c|}{ Vaubarnier } & \multicolumn{2}{c}{ Rimbaud } \\
\hline January & -0.205 & - & -0.242 & - & -0.216 & - & -0.377 & - & -0.485 & - & -1.297 & - \\
February & -0.347 & - & -0.342 & - & -0.489 & - & -0.540 & $* * *$ & -0.403 & - & -1.157 & - \\
March & -0.480 & $* *$ & -0.522 & $* * *$ & -0.570 & - & -0.872 & $* *$ & -0.862 & $* *$ & -1.304 & $* *$ \\
April & -0.423 & $*$ & -0.368 & $* *$ & -0.570 & $*$ & -0.561 & $*$ & -0.655 & $*$ & -1.080 & $*$ \\
May & -0.136 & $* * *$ & -0.144 & - & -0.172 & - & -0.292 & $* * *$ & -0.334 & $* * *$ & -0.348 & $* * *$ \\
June & -0.034 & - & -0.013 & - & -0.043 & - & -0.090 & $* * *$ & -0.110 & - & -0.034 & - \\
July & -0.004 & - & 0.000 & - & 0.000 & - & -0.003 & - & -0.036 & - & -0.004 & - \\
August & 0.000 & - & 0.000 & - & 0.000 & - & 0.000 & - & -0.008 & - & 0.000 & - \\
September & -0.002 & - & 0.000 & - & 0.000 & - & 0.000 & - & -0.040 & $* * *$ & 0.000 & - \\
October & -0.014 & - & -0.016 & - & 0.000 & - & -0.011 & - & -0.100 & $* * *$ & 0.000 & - \\
November & 0.122 & - & 0.223 & - & 0.319 & - & 0.046 & - & -0.048 & - & 0.448 & - \\
December & 0.029 & - & 0.180 & - & 0.176 & - & -0.077 & - & 0.037 & - & 0.123 & - \\
\hline Year & -1.987 & - & -3.537 & - & -2.466 & - & -4.866 & $* * *$ & -3.801 & - & -6.357 & - \\
Amax1d & -0.062 & - & -0.083 & - & -0.030 & - & -0.098 & - & -0.033 & - & -0.065 & - \\
\hline
\end{tabular}

${ }^{*} P<0.01 .{ }^{* *} P<0.05 .{ }^{* * *} P<0.1$. A dash (-) means not significant.

Table 6. Sen's slope of linear trends and the value of the Mann-Kendall test in indices of low flows for each catchment. Symbols represent significance level $P$ according to the Mann-Kendall test. The mean values of the two methods of calculating BFI are given in the last two lines.

\begin{tabular}{|c|c|c|c|c|c|c|c|c|c|c|c|c|}
\hline & \multicolumn{2}{|c|}{ Pont de Fer } & \multicolumn{2}{|c|}{ Malière } & \multicolumn{2}{|c|}{ Valescure } & \multicolumn{2}{|c|}{ Maurets } & \multicolumn{2}{|c|}{ Vaubarnier } & \multicolumn{2}{|c|}{ Rimbaud } \\
\hline Start & -0.214 & - & 0.400 & - & -0.151 & - & -0.024 & - & -0.410 & - & -0.375 & $*$ \\
\hline Centre & 0.188 & - & 0.528 & * & 0.267 & - & 0.333 & - & 0.438 & $* * *$ & 0.000 & - \\
\hline End & 0.607 & $* *$ & 0.500 & - & 0.477 & $* * *$ & 0.556 & - & 0.500 & - & 0.171 & - \\
\hline LFD & 0.875 & - & 0.243 & - & 0.409 & - & 1.091 & - & 2.143 & $*$ & 0.875 & $* * *$ \\
\hline DEF & 0.011 & - & 0.007 & - & 0.001 & - & 0.028 & - & 0.100 & $* *$ & 0.005 & - \\
\hline BFI_L & -0.001 & - & 0.003 & $*$ & 0.000 & - & 0.000 & - & -0.002 & - & -0.001 & - \\
\hline Bflow_L & -0.960 & $* *$ & -0.785 & - & -1.294 & - & -1.639 & - & -1.841 & - & -2.604 & * \\
\hline BFI_F & -0.0003 & - & 0.0022 & $*$ & -0.0002 & - & -0.0006 & - & -0.0013 & - & -0.0007 & - \\
\hline Bflow_F & -0.865 & $* *$ & -0.873 & - & -1.162 & - & -1.591 & - & -1.748 & - & -2.339 & * \\
\hline mean BFI_L & 0.308 & & 0.332 & & 0.29 & & 0.332 & & 0.388 & & 0.211 & \\
\hline mean BFI_F & 0.302 & & 0.311 & & 0.289 & & 0.321 & & 0.367 & & 0.21 & \\
\hline
\end{tabular}

${ }^{*} P<0.01 .{ }^{* *} P<0.05$. ${ }^{* * *} P<0.1$. A dash (-) means not significant

in March and April flows in most catchments. The sequential Mann-Kendall test statistic detects significant change points in SFI calculated on periods above 6 months. The test indicates a change point in 1980 for all catchments, except the Vaubarnier sub-catchment with a change point in 1989.

\section{Discussion}

The monthly flows show a significant decreasing trend for spring flows for six catchments, in March and April. The Maurets sub-catchment is the only catchment showing a significant decrease in monthly flows for 6 months from February to June (the high-flow period). This persistent decrease in these seasonal flows explains why the only significant decrease in annual flows was observed for this catchment. In addition, the Vaubarnier catchment is the only one to present a significant decrease in September and October flows. For this catchment, the decrease in these monthly flows is confirmed by the significant increase in the low-flow volume deficit and the low-flow duration. Among the other catchments, two of them (Pont de Fer and Rimbaud) show a significant decrease in base flow (BFlow), associated with a significant lengthening of the low-flow period. In this section we try to understand the reasons for this change. These trends and their variability within the whole catchment can be explained by several factors that are detailed below. 
Table 7. Sen's slope of linear trends and the value of the Mann-Kendall test in SFI indices for each catchment. Symbols represent significance level $P$ according to the Mann-Kendall test.

\begin{tabular}{llr|rr|r|r|r|rr|rr|rr}
\hline SFI & \multicolumn{2}{c}{ Pont de Fer } & \multicolumn{2}{c|}{ Malière } & \multicolumn{2}{c|}{ Valescure } & \multicolumn{2}{c|}{ Maurets } & \multicolumn{2}{c|}{ Vaubarnier } & \multicolumn{2}{c}{ Rimbaud } \\
\hline 1 & -0.0008 & $* *$ & -0.0004 & - & -0.0003 & - & -0.0010 & - & -0.0012 & $* *$ & -0.0008 & $* *$ \\
3 & -0.0009 & $* * *$ & -0.0007 & - & -0.0004 & - & -0.0012 & - & -0.0013 & $*$ & -0.0010 & $* *$ \\
6 & -0.0009 & - & -0.0009 & - & -0.0004 & - & -0.0013 & - & -0.0014 & $* *$ & -0.0013 & $* *$ \\
9 & -0.0009 & - & -0.0008 & - & -0.0005 & - & -0.0014 & - & -0.0015 & $* * *$ & -0.0012 & $* *$ \\
12 & -0.0009 & - & -0.0009 & - & -0.0006 & - & -0.0014 & - & -0.0016 & $* * *$ & -0.0013 & $* *$ \\
24 & -0.0010 & - & -0.0011 & - & -0.0007 & - & -0.0017 & - & -0.0019 & - & -0.0015 & $* * *$ \\
\hline
\end{tabular}

${ }^{*} P<0.01 .{ }^{* *} P<0.05$. ${ }^{* * *} P<0.1$. A dash (-) means not significant.

\subsection{Climatic factors}

A decrease in flow rates is often related to a decrease in rainfall. However, annual rainfall has not exhibited any trend, as reported in Chaouche et al. (2010), who did not detect any significant trends in annual precipitation in the Mediterranean region during 1970-2006. Only a significant downward trend in March precipitation, with a decrease in wet days (thresholds between 2 and $20 \mathrm{~mm} \mathrm{~d}^{-1}$ ) and a longer dry spell, was detected in the catchment. These factors can have a direct impact on the decrease in flows and changes in the genesis of runoff.

Evapotranspiration is a key flux controlling the surface water balance. It is basically determined by the potential evapotranspiration (PET), which represents the climatic demand, and the upper soil wetness, which represents the actual amount of water that can be mobilized. In order to evaluate the climatic demand, temperatures from the nearest MétéoFrance climatological station in the reference homogenized French climatic network (Le Cannet des Maures) from 1959 to 2011 and the monthly PET calculated by the PenmanMonteith (Allen et al., 1998) formula for the Toulon station from 1959 to 2014 were studied (Table 8).

At the annual scale, the mean temperature shows significant changes with $+1.6^{\circ} \mathrm{C}$ from 1959 to 2011 , i.e. $+0.3^{\circ} \mathrm{C}$ per decade. This value is consistent with those of Chaouche et al. (2010), who noted the same rates in the French Mediterranean region, and with Lespinas et al. (2010), who observed an increase of $+1.4^{\circ} \mathrm{C}$ from 1965 to 2004 in LanguedocRoussillon. At the monthly scale, there is a significant increase in temperature in the spring and summer months. The months with the strongest warming are August and May. The temperature also increased in winter (December) but with a lower magnitude. Annual PET displays an upward significant trend with an amplitude of $+1.6 \mathrm{~mm} \mathrm{yr}^{-1}$, confirmed by the results of Chaouche et al. (2010), who found a trend varying from +1 to $+4 \mathrm{~mm} \mathrm{yr}^{-1}$. Significant changes in monthly PET show upward trends in some months. No trends are seen in monthly PET in April, May, or August whereas significant trends in monthly temperature are observed. These discrepancies can be explained by differences in the local climatic conditions, Toulon being at the seashore, south of the catchment, while the Cannet des Maures is situated inland, north of the catchment.

To combine PET and soil wetness, the GR4J model (Perrin et al., 2003) was applied over the whole catchment (Pont de Fer) from 1968 to 2015. Tendency tests were applied to the annual time series of the mean reservoir levels that represent the amount of water in the upper soil and showed a decrease, with a particularly low level in 1989 and 2007. In addition, outputs from a reanalysis of soil wetness by the SAFRANISBA-MODCOU model (Habets et al., 2008; Vidal et al., 2010) were tested, showing the same significant decrease in soil wetness. Hence, it is clear that the increase in evaporation demand, combined with a rainfall decrease in March, tends to dry the upper soil, reducing the water supply to the different catchments.

\subsection{Catchment characteristics and functioning}

There are common trends between the catchments, such as a greater severity of the low-flow period, but the response differs according to the sub-catchment.

Firstly, the size of the watershed seems to be an explanatory factor for these differences. For example, the smaller the catchment the more sensitive it is to climate variation. This is the case for the Rimbaud and Vaubarnier catchments, although their sensitivity to climate variation is totally different. Secondly, the physiographic characteristics of the catchments (topography, geology, lithology, etc.) imply different sensitivities of the catchments to climatic changes. Thirdly, the water storage capacity of watersheds seems to be an important explanatory factor of the different impacts of climatic variations on flows. The greater the storage capacity of the catchment or the slower the dynamics of the catchment, the less the low flows will be affected by a decrease in rainfall and an increase in temperature. This is explained by the decrease in underground flows and their contribution to base flows. This is the case of the two catchments of Maurets and Vaubarnier, which have the lowest dynamics and are characterized by a higher infiltration capacity.

In order to give more details about the interpretation of trend analyses on SPI and SFI, a homoscedasticity test was 
Table 8. Sen's slope of linear trends and value of Mann-Kendall test in PET at Toulon and $T$ at Le Cannet des Maures. Symbols represent significance level $P$ according to the Mann-Kendall test.

\begin{tabular}{|c|c|c|c|c|c|c|c|c|}
\hline \multirow[b]{2}{*}{ January } & \multicolumn{2}{|c|}{$\operatorname{PET}\left(\mathrm{mm} \mathrm{yr}^{-1}\right)$} & \multicolumn{2}{|c|}{$T_{\min }\left({ }^{\circ} \mathrm{C} \mathrm{yr}^{-1}\right)$} & \multicolumn{2}{|c|}{$T_{\text {moy }}\left({ }^{\circ} \mathrm{C} \mathrm{yr}^{-1}\right)$} & \multicolumn{2}{|c|}{$T_{\max }\left({ }^{\circ} \mathrm{C} \mathrm{yr}^{-1}\right)$} \\
\hline & 0.069 & - & 0.007 & - & 0.013 & - & 0.020 & - \\
\hline February & 0.105 & $* *$ & -0.013 & - & 0.003 & - & 0.024 & - \\
\hline March & 0.171 & $* *$ & 0.008 & - & 0.026 & $* *$ & 0.036 & * \\
\hline April & 0.098 & - & 0.020 & $* *$ & 0.024 & $* * *$ & 0.023 & $* *$ \\
\hline May & 0.133 & - & 0.043 & $*$ & 0.043 & $* *$ & 0.047 & * \\
\hline June & 0.238 & $*$ & 0.038 & * & 0.043 & $*$ & 0.049 & * \\
\hline July & 0.250 & $*$ & 0.044 & $*$ & 0.037 & $*$ & 0.027 & ** \\
\hline August & 0.100 & - & 0.050 & $*$ & 0.048 & $*$ & 0.054 & * \\
\hline September & 0.232 & $*$ & 0.016 & - & 0.019 & $* * *$ & 0.029 & $* * *$ \\
\hline October & 0.100 & $* * *$ & 0.035 & $* *$ & 0.027 & $* *$ & 0.017 & - \\
\hline November & 0.086 & $* * *$ & 0.017 & - & 0.019 & - & 0.018 & $* * *$ \\
\hline December & 0.047 & - & 0.031 & $* * *$ & 0.022 & $* * *$ & 0.013 & - \\
\hline Year & 1.576 & $* *$ & 0.007 & - & 0.031 & $*$ & 0.039 & * \\
\hline
\end{tabular}

realized by the Bartlett's test (1937). This test is used to test whether different samples have equal variances. We verified the homogeneity of variances for SPI and SFI accumulated on 1 month to 24 months (with a $p$ value of $5 \%$ to accept H0 hypothesis: identical variance). We compared the variance calculated over the first 25 years (P1) and over the last 25 years (P2). The SPI variance was found to be homogeneous over the two periods, with the exception of the SPI24, for which the $\mathrm{P} 1$ variance is higher than $\mathrm{P} 2$ variance.

As for the previous results on the SFI, the results of the homoscedasticity test on SFI depend essentially on the hydrological functioning. So, the catchments characterized by a hydrological functioning mainly controlled by precipitation (Rimbaud, Valescure) show a significant increase in SFI variability, for SFI accumulated on scale of 1 month to 6 months. This suggests that these watersheds are more influenced by decreasing precipitation, creating more of a gap between high- and low-water periods. For the catchments characterized by a lower dynamic (Vaubarnier and Mauret), the test indicates a significant decrease in SFI variability for longer accumulation (SFI12 and SFI24). This is probably related to the presence of longer periods of drought over the period P2, reducing the variability of mean flows.

\subsection{Land use}

Trends in flows may also be due to changes in land use. As many studies have shown, the evolution of land use over the years can affect the regime of rivers (Hibbert, 1967; Hewlett, 1982; Andréassian, 2004; Brown et al., 2005; Ssegane et al., 2013). These disturbances are generally caused by human actions, such as urbanization, deforestation and agriculture, or by natural causes such as fires. This point was disregarded in our explanations because the Réal Collobrier watershed is a forest catchment area that has been weakly impacted by human activity for the last 50 years. The only urban area (the village of Collobrières) has not extended much and is located downstream of the six sub-catchments studied. Only the Rimbaud catchment was burnt by forest fires in 1990 ( $80 \%$ of its surface). Studies on the impact of this fire on the flows showed that the flood dynamics were impacted only during a period of 4 years after the fire (Folton et al., 2015; Lavabre et al., 1998, 2000). No impact was observed on the annual flows or low flows in this catchment. These arguments suggest that the physiographic and land cover characteristics of the watershed have remained relatively stable over the last 50 years and cannot be considered an explanatory factor for the flow trends.

\section{Conclusions}

The analysis of the 1968-2017 period of the Réal Collobrier catchment data shows a decrease in rainfall in March and a decrease in rainfall duration.

With the observed increase in temperatures and PET, climatic factors show a tendency to decrease the amount of water available for watersheds. This is observed globally in all of the sub-watersheds studied, especially in spring and during the low-flow period.

Hydrological factors modulate the climatic trends among the sub-catchments. Depending on their hydrological functioning, the impact of a climatic change leads to responses that can be highly contrasted. Flows respond not only to the magnitude of changes in rainfall and temperature but also to the timing of these changes. Thus, significant reductions observed in spring rainfall lead to changes in spring, summer or autumn flows, depending on catchment characteristics. For example, there is a direct link between same-season climate and flow changes in the Rimbaud catchment where spring 
flows show a clear relationship with spring precipitation and spring to summer temperature. This is definitely due to the low storage capacity of this catchment, associated with little "hydrological memory". Spring flow decreases with precipitation but also with increased temperature associated with a higher evapotranspiration demand. In this catchment, the increase in summer temperature (and potential evapotranspiration) is not associated with a decrease in summer flow (because of large periods of null-flow periods over all the 50year series), but with a significant lengthening of the lowflow period.

This study shows also that the catchments that usually support low flows are the most sensitive to climatic disturbances. Unlike the Rimbaud catchment, the Vaubarnier catchment reflects a large storage capacity (the higher mean BFI) that delays the climate to low-flow response. So, significant changes in spring precipitation, combined with increased spring and summer temperature and evapotranspiration demand, have influence on significant decreases in spring, summer and autumn flows. As a result, the length of the severe continuous low-flow periods increases significantly, and the volume deficit of drought increases as well.

The Maurets catchment, which also has a slow hydrological process, shows a relatively important range of change in monthly flows, with a significant decrease from February to June. The Valescure catchment, close to the previous one, shows contrast. The significant decrease concerns only the flows for the month of April. And on the Pont de Fer catchment, the outlet of the study area, the trends in the hydrological indices are more smoothed, except for the significant decrease in base flow.

The fine-scale hydrological information obtained thanks to the Réal Collobrier research catchment has enabled us to observe that at this fine scale the impact of a climatic variation in the hydrology is much more variable than the variability imposed by the climate. The rainfall-runoff relationship is complex, and multiple nonlinearities (between flow and climatic variables such as rainfall or temperature) make it difficult to understand and to quantify the influence of the detected change in climate on the water resource. However, this appears to be specific to small watersheds. This has to be considered as an important result too as it underlines the complex functioning at small scales. The response of a particular watershed to climatic change integrates not only the climate input, but also changes in storage, as well as change and variability in the hydrology of the watershed.

The reliable evaluation of trends requires the availability of data in catchments that are near-natural and unregulated, contain long records lengths, are active gauged catchments, and have good-quality data. The Réal Collobrier research catchment is part of the French reference hydrological observatory (http://www.ozcar-ri.org/real-collobrier/, last access: December 2017) and is particularly suitable for this assessment. These catchments constitute an exceptionally valuable data source to effectively identify, quantify and interpret hy- drological change in an area weakly influenced by human activities. Most studies in the literature analysing flow variability (e.g. Giuntoli et al., 2013; Lespinas et al., 2010) are based on samples of catchments with few small catchments (less than $10 \mathrm{~km}^{2}$ ). Hence the data on the research catchment of Réal Collobrier allow us to study the flow variations in these small catchments in connection with the climate.

The measures in the catchments will be continued and enriched in the future according to need. These measures will be completed by modelling to better document climaterelated drivers of change. Concerning hydrological functioning and land use changes, reforestation experimentation on the Malière catchment planned in the future will be analysed.

Data availability. The data on Real Collobier catchment are accessible to everyone as long as the users register on the application and observe the terms of use on Data Base BDOH. The Hydrology Observatory Database (Base de Données des Observatoires en Hydrologie, BDOH) aims at managing, banking and providing hydrological and biochemical data from long-term observatories managed by Irstea or where Irstea is strongly involved. These data can be downloaded freely for non-commercial purposes at https://bdoh.irstea.fr/ (last access: May 2017) (Tolsa et al., 2015). These data remain the property of Irstea. For more detail refer to the French licence agreement on the website or contact bdoh.support@lists.irstea.fr.

Author contributions. TM collected the data. FN and LP conceived and designed the analysis. FN performed the calculations and analysed the results. AP and ME contributed to the interpretation of the results. FN, ME, AP wrote and prepared the paper with contribution from all co-authors.

Competing interests. The authors declare that they have no conflict of interest.

Special issue statement. This article is part of the special issue "Hydrological cycle in the Mediterranean (ACP/AMT/GMD/HESS/NHESS/OS inter-journal SI)". It is not associated with a conference.

Acknowledgements. Data from the SAFRAN-ISBA-MODCOU were provided by François Besson (Météo-France, Direction de la climatologie et des services climatiques). Data from the Cannet des Maures Station (temperature) and Toulon (PET) were provided by Météo-France. We also would like to acknowledge the review of two anonymous reviewers for valuable suggestions.

Review statement. This paper was edited by Giuseppe Tito Aronica and reviewed by two anonymous referees. 


\section{References}

Allen, R. G., Pereira, L., Raes, D., and Smith, M.: Crop evapotranspiration - Guidelines for computing crop waters requirements FAO irrigation and drainage paper 56; chapters $1,2,3 \& 4$, annex $3 \& 5,1998$.

Andréassian, V.: Waters and forests: from historical controversy to scientific debate, J. Hydrol., 291, 1-27, 2004.

Balme-Debionne, S.: Analyse du régime pluviométrique sahélien dans une perspective hydrologique et agronomique, Etude de l'impact de sa variabilité sur la culture du mil, Thèse INP Grenoble, 162 pp., 2004.

Barker, L. J., Hannaford, J., Chiverton, A., and Svensson, C.: From meteorological to hydrological drought using standardised indicators, Hydrol. Earth Syst. Sci., 20, 2483-2505, https://doi.org/10.5194/hess-20-2483-2016, 2016.

Bartlett, M. S.: Properties of sufficiency and statistical tests. P. Roy. Soc. A-Math. Phy., 160, 268-282, https://doi.org/10.1098/rspa.1937.0109, 1937.

Beard, L. R.: Statistical analysis in hydrology, ASCE Trans., 108, 1110-1160, 1943.

Bisai, D., Chatterjee, S., Khan, A., and Barman, N. K.: Application of sequential Mann-Kendall test for detection of approximate significant change point in surface air temperature for Kolkata weather observatory, West Bengal, India International Journal of Current Research, 6, 5319-5324, 2014.

Brodie, R. S. and Hostetler, S.: A Review of Techniques for analysing Baseflow from Stream Hydrographs, B. o. R. Sciences, Canberra, 5 pp., 2005.

Brown, A. E., Zhang, L., MacMahon, T. A., Western, A. W., and Vertessy R. A.: A review of paired catchment studies for determining changes in water yield resulting from alterations in vegetation, J. Hydrol., 310, 28-61, 2005.

Cantat, O.: Analyse critique sur les tendances pluviométriques du 20e siècle en basse Normandie : réflexion sur la fiabilité des données et le changement climatique. Annale de l'Association Internationale de Climatologie, Vol. 1, 31 pp., 2004.

Chaouche, K., Neppel, L., Dieulin, C., Pujol, N., Ladouche, B., Martin, E., Salas, D., and Caballero Y.: Analyses of precipitation, temperature and evapotranspiration in a French Mediterranean region in the context of climate change, C. R. Geosci., 342, 234243, ISSN 1631-0713, 2010.

Conover, W. L.: Pratical nomparametric statistics, 3rd edition, Wiley \& Sons, p. 584, 1999.

De la Casa, A. and Ovando, G. G.: Variation of reference evapotranspiration in the central region of Argentina between 1941 and 2010, J. Hydrol., 5, 66-79, 2016.

Douglas, E. M., Vogel, R. M., and Kroll, C. M.: Trends in flood and low flows in the United States: impact of spatial correlation, J. Hydrol., 240, 90-105, 2000.

Drobinski, P., Ducrocq, V., Alpert, P., Anagnostou, E., Béranger, K., Borga, M., Braud, I., Chanzy, A., Davolio, S., Delrieu, G., Estournel, C., Boubrahmi, N.F., Font, J., Grubišić, V., Gualdi, S., Homar, V., Ivančan-Picek, B., Kottmeier, C., Kotroni, V., Lagouvardos, K. , Lionello, P., Llasat, M.C., Ludwig, W., Lutoff, C., Mariotti, A., Richard, E., Romero, R. , Rotunno, R., Roussot, O., Ruin, I., Somot, S., Taupier-Letage, I., Tintore, J., Uijlenhoet, R., and Wernli, H.: HyMeX: A 10-Year Multidisciplinary Program on the Mediterranean Water Cycle, B. Am. Meteo- rol. Soc., 95, 1063-1082, https://doi.org/10.1175/BAMS-D-12$00242.1,2014$.

Eckstein, B. A.: Evaluation of spline and weighted average interpolation algorithms, Computers and Geosciences, 15, 79-97, 1989.

Folton, N., Tolsa, M., and Arnaud, P.: Le Bassin de recherche du Réal Collobrier, Étude des processus hydrologiques en milieu méditerranéen a échelle fine, Actes du Colloque 50 ans de l'Orgeval et 37èmes journées du GFHN, Paris, FRA, IRSTEA, 7 pp., 2012.

Folton, N., Andréassian V., and Duperray, R.: Hydrological impact of forest fire from paired catchment and rainfall-runoff modelling perspectives, Hydrolog. Sci. J., 60, 1213-1224, https://doi.org/10.1080/02626667.2015.1035274, 2015.

Gao, Z., He, J., Dong, K., and Lin, X.: Trends in reference evapotranspiration and their causative factors in the West Lia River basin China, Agr. Forest Meteorol., 232, 106-117, 2017.

Gerstengarbe, F. W. and Werner P. C.: Estimation of the beginning and end of recurrent events within a climate regime, Clim. Res., 11, 97-107, 1999.

Giuntoli, I., Renard, B., Vidal J. P., and Bard, A.: Low Flows in France and their relationship to large scale climate indices, J. Hydrol., 482, 105-118, 2013.

Gocic, M. and Trajkovic, S.: Analysis of changes in meteorological variables using Mann-Kendall and Sen's slope estimator statistical tests in Serbia, Global Environ. Chang., 100, 172-182, 2013.

Gregor, M.: Methodology, in: Surface- and Groundwater Quality Changes in Periods of Water Scarcity, Springer Theses (Recognizing Outstanding PhD Research), Springer, Berlin, Heidelberg, 3-54, 2013.

Guttman, N. B.: Accepting the "Standardized Precipitation Index": a calculation algorithm index, J. Am. Water Resour. As., 35, 311$322,1999$.

Gustard, A. and Tallaksen, L.: Low-Flow indices in Manual on Low-Flow, Estimation and Prediction, Operational Hydrology report (50), edited by: Gustard, A., and Demuth, S., WMO (1029), 43-49, 2008.

Habets, F., Boone, A., Champeaux, J. L., Etchevers, P., Franchistéguy, L., Leblois, E., Ledoux, E., Le Moigne, P., Martin , E., Morel S., Noilhan, J., Quintana Segui, P., Rousset-Regimbeau, F., and Viennot, P. :The SAFRAN-ISBA-MODCOU hydrometeorological model applied over France, J. Geophys. Res., 113, D06113, https://doi.org/10.1029/2007JD008548, 2008.

Hamed, K. H.: Trend detection in hydrology data: The MannKendall trends test under the scaling hypothesis, J. Hydrol., 349, 350-363, 2008.

Hamed, K. H. and Rao, A. R.: A modified Mann-Kendall trend test for auto correlated data, J. Hydrol., 204, 182-196, 1998.

Hayes, M. J., Svoboda, M. D., Wall, N., and Widhalm, M.: The Lincoln Declaration on Drought Indices - Universal meteorological drought index recommended, B. Am. Meteorol. Soc., 92, 485488, 2011.

Helsel, D. R. and Hirsch, R. M.: Statistical method in water resources, Techniques of Water-Resources Investigations of the United States Geological Survey, Book 4, available at: https://pubs.usgs.gov/twri/twri4a3/pdf/twri4a3-new.pdf (last access: June 1991), Hydrologic Analysis and Interpretation, 2002.

Hertig, E. and Tramblay, Y.: Regional downscaling of Mediterranean droughts under past and future climatic conditions, Cli- 
mate variability and change in the Mediterranean region, Global Environ. Chang., 151, 36-48, ISSN 0921-8181, 2017.

Hewlett, J. D.: Principles of forest hydrology, The University of Georgia Press, Athens, 183 pp., 1982.

Hibbert, A. R.: Forest treatment effects on water yield in Forest Hydrology, Proceedings of the National Science Foundation Advanced Science Seminar, 257-543, 1967.

Hipel, K. W. and McLeod, A. I.: Time Series Modelling of Water Resources and Environmental Systems, Electronic reprint of our book orginally published in 1994, 1013 pp., 2005.

Hisdal, H., Clausen, B., Gustard, A., Peters, E., and Tallaksen, L. M.: Event Definitions and Indices, in: Hydrological Drought Processes and Estimation Methods for Streamflow and Groundwater, edited by: Tallaksen, L. M. and van Lanen, H. A. J., Dev. Water Sci., 48, 139-198, 2004.

Institute of Hydrology: Low Flows Studies Report, 3 volumes, Institute of Hydrology, Wallingford, UK, 1980.

Javanmard, S., Emanhadi, M., Bodaghjamali, J., and Didehvarasl, A.: Spatial temporal analysis of drought in Iran using SPI during a long term period, Earth Sci., 6 15-29, 2017.

Jhajharia, D., Dinpashoh, Y., Kahya, E., Singh, P. V., and FakheriFard, A.: Trends in reference evapotranspiration in the humid region of northeast India, Hydrol Proc., 26, 421-435, 2012.

Jhajharia, D., Dinpashoh, Y., Kahya, E., Choudhary, R. R., and Singh, V. P.: Trends in temperature over Godavari River basin in Southern Peninsular India. Int. J. Climatol., 34, 1369-1384, 2013.

Kendall, M. G.: Rank Correlation Methods - Griffin, London, UK, 202 pp., 1975.

Kumar, M., Denis, M. D., and Suryavanshi, S.: Long-term climatic trend analysis of Giridih district, Jharkland (India) using statistical approach, Model. Earth Syst. Environ., 2, 112, https://doi.org/10.1007/s40808-016-0162-2, 2016.

Kumar, S., Merwade, V., Kam, J., and Thurner, K.: Streamflow trends in Indiana: effects of long term persistence, precipitation and subsurface drains, J Hydrol., 374, 171-183, 2009.

Laaha, G., Gauster, T., Tallaksen, L. M., Vidal, J.-P., Stahl, K., Prudhomme, C., Heudorfer, B., Vlnas, R., Ionita, M., Van Lanen, H. A. J., Adler, M.-J., Caillouet, L., Delus, C., Fendekova, M., Gailliez, S., Hannaford, J., Kingston, D., Van Loon, A. F., Mediero, L., Osuch, M., Romanowicz, R., Sauquet, E., Stagge, J. H., and Wong, W. K.: The European 2015 drought from a hydrological perspective, Hydrol. Earth Syst. Sci., 21, 3001-3024, https://doi.org/10.5194/hess-21-3001-2017, 2017.

Ladson, A. R., Brown, R., Neal, B., and Nathan R.: A Standard Approach to Baseflow Separation Using The Lyne and Hollick Filter, Australian Journal of Water Resources, 17, 2534,https://doi.org/10.7158/13241583.2013.11465417, 2015.

Lavabre, J.: Research drainage basin of the Real Collobrier: Flow modelisation regional analysis, Flow Regimes from International experimental and Network Data sets, publication IAHS, 187, 423-434, 1989.

Lavabre, J., Aranud, P., Folton, N., and Michel, C.: Hydrological response of a little Mediterranean basin flows after fire, Conférence internationale: XXII General Assembly, E.G.S., Nice 20-24 April 1998.

Lavabre, J., Martin, C., and Folton, N.: Impact de l'incendie sur le comportement hydrologique du bassin versant, Chapitre III, in: Conséquences d'un incendie de forêt dans le bassin ver- sant du Rimbaud (massif des Maures, Var, France): destruction et régénération du couvert végétal, impacts sur l'hydrologie, l'hydrochimie et les phénomènes d'érosion mécanique, Cemagref Editions, Coll. Etudes, Gestion des milieux aquatiques, 16, 33-49, 2000.

Lee, S. H., Yoo, S. H., Choi, J. Y., and Bae, S.: Assessment of the impact of climate change on drought characteristics in the Hwanghae plain, North Korea using time series SPI and SPEI: 1981-210, MDPI, 9, 1-19, 2017.

Lespinas, F., Ludwig, W., and Heussner, S.: Impact of recent climate change on the hydrology of coastal Mediterranean rivers in Southern France, Climatic Change, 99, 425-456, 2010.

Lorenzo-Lacruz, J., Morán-Tejeda, E., Vicente-Serrano, S. M., and López-Moreno, J. I.: Streamflow droughts in the Iberian Peninsula between 1945 and 2005: spatial and temporal patterns, Hydrol. Earth Syst. Sci., 17, 119-134, https://doi.org/10.5194/hess17-119-2013, 2013.

Louvet, S., Paturel, J. E., Mahe, G., Vigaud, N., Roucou, P., Rouche, N., and Koite, M.: Past and future spatio-temporal variability of rainfall of the Bani catchment in West Africa. Hydroclimatology: Variability and Change (processing of symposium in Melbourne, Australia, July 2011), IAHS Publ., 344, 125-130, 2011.

Lyne, V. D. and Hollick, M.: Stochastic time-variable rainfall-runoff modelling, Hydrology and Water Resources Symposium, Perth, Institution of Engineers, Australia, 79 pp., 1979.

McKee, T. B., Doesken, N. J., and Kleist, J.: The relationship of drought frequency and duration of time scales, Eighth Conference on Applied Climatology, American Meteorological Society, 202 pp., 1993.

Mann, H. B.: Nonparametric tests against trend, Econometrica, 13, 245-259, https://doi.org/10.2307/1907187, 1945.

Martin, C.: L'érosion différentielle dans la région de Collobrières, Massif des Maures - Var, Méditerranée, deuxième série tome, 11, 159-170, 1972.

Nathan, R. J. and McMahon, T. A.: Evaluation of automated techniques for base flow and recession analyses, Water Resour. Res., 26, 1465-1473, 1990.

Perrin, C., Michel, C., and Andreassian, V.: Improvement of a parsimonious model for streamflow simulation, J. Hydrol., 279, 275289, 2003.

Peterson, T. C., Folland, C., Griza, G., Hogg, W., Mokssit, A., and Plummer, N.: Report on the Activities of the Working Group on Climate Change Detection and Related Rapporteurs 1998-2001, WMO, Rep. WCDMP-47, WMO-TD 1071, Genève, Switzerland, 143 pp., 2001.

Pujol, N., Neppel, L., and Sabatier, R.: Regional tests for trend detection in maximum precipitation series in the French Mediterranean region, Hydrolog. Sci. J., 52, 956-973, https://doi.org/10.1623/hysj.52.5.956, 2007.

Ribes, A., Thao, S., Vautard, R., Dubuisson, B., Somot, S., Colin, J., Planton, S., and Soubeyroux, J.-M.: Observed increase in extreme daily rainfall in the French Mediterranean, Clim. Dynam., 52, 1095-114, https://doi.org/10.1007/s00382-018-41792, 2018.

Sen, P. K.: Estimates of the regression coefficient based on Kendall's Tau, J. Am. Stat. Assoc., 63, 1379-1389, 1968.

Sicard, P.: Caractérisation des retombées atmosphériques en France en zone rurale sous forme de précipitations, gaz et 
aérosols, Analyse des tendances spatio-temporelles et des séries chronologiques, PhD Dissertation, University Lille, France, 426 pp., 2006.

Smathkin, Y. V. and Watkins, D. A.: Lowflow estimation in South Africa, Water research Commission, Report No. 494/1/97, Pretoria, South Africa, 1967.

Sneyres, R.: On the statistical Analysis of Time Series of Observation Technical Note No. 143, World Meteorological Organisation, Geneva, 1990.

Ssegane, H., Amatya, D., Chescheir, G., Skaggs, W., Tollner, E., and Nettles, J.: Consistency of Hydrologic Relationships of a Paired Watershed Approach, American Journal of Climate Change, 2, 147-164, https://doi.org/10.4236/ajcc.2013.22015, 2013.

Stagge, J. H., Tallaken, L. M., Gudmundsson, L., Loon, A. F., and Stahl, K.: Candidate distributions for climatological drought indices (SPI and SPEI), Int. J. Climatol., 35, 4027-4040, https://doi.org/10.1002/joc.4267, 2015.

Stewart, I. T., Cayan, D. R., and Dettinger, M. D.: Changes toward earlier streamflow timing across western North America, J. Climate, 18, 1136-1155, 2005.

Tabari, H., Somee, B. S., and Zadech, M. R.: Testing for long-term trends in climatic variables in Iran, Atmos. Res., 100, 132-140, 2011.

Tolsa, M., Folton, N., and Arnaud, P.: Bassin versant expérimental du Réal Collobrier (Data set), Irstea, https://doi.org/doi.org/10.17180/obs.real, 2015.

Hisdal, H., Tallaksen L. M., Clausen, B., Peters, E., and Gustard, V. L.: Hydrological Drought Characteristics in: Hydrological Drought, Processes and Estimation Methods for Streamflow and Groundwater, edited by: Tallaksen L. M. and Van Lanen, H. A. J. Developments in Water Science 48, Elsevier, Amsterdam, 139198, 2004.

Theil, H.: A rank invariant method of linear and polynomial regression analysis: par 3, Nederland's Akad, Wetensch. Proc., 53, 1397-1412, 1950.

Tramblay, Y., Neppel, L., Carreau, J., and Najib, K.: Non-stationary frequency analysis of heavy rainfall events in Southern France, Hydrol. Sci. J., 58, 280-294, 2013.
Venables, W. N. and Ripley, B. D.: Modern applied Statistics with S. Fourth Edition Springer Verlag, 498 pp., 2002.

Vicente-Serrano, S. M., López-Moreno, J. I., Beguería, S., LorenzoLacruz, J., Azorin-Molina, C., and Morán-Tejeda, E.: Accurate computation of a streamflow drought index, J. Hydrol. Eng., 17, 318-332, https://doi.org/10.1061/(ASCE)HE.19435584.0000433, 2012.

Vidal, J.-P., Martin, E., Franchistéguy, L., Habets, F., Soubeyroux, J.-M., Blanchard, M., and Baillon, M.: Multilevel and multiscale drought reanalysis over France with the Safran-Isba-Modcou hydrometeorological suite, Hydrol. Earth Syst. Sci., 14, 459-478, https://doi.org/10.5194/hess-14-459-2010, 2010.

Vogel, R. M. and Fennessey, N. M.: Flow duration curves (2), New interpretation and confidence intervals, J. Water Res. Pl., 120, 485-504, 1995a.

Vogel, R. M. and Fennessey, N. M.: Flow duration curves (2), A review of applications in water resources planning, Water Resour. Bull., 31, 1029-1039, 1995b.

Yacoub, E. and Tayfur, G.: Evaluation and assessment of meteorological drought by different methods in Trarza regions, Mauritania, Water Resour. Manag., 31, 825-845, 2017.

Yang, X., Xie, X., Liu De, L., Ji, F., and Wang, L.: Spatial Interpolation of Daily Rainfall Data for Local Climate Impact Assessment over Greater Sydney Region, Adv. Meteorol., 2015, 563629, https://doi.org/10.1155/2015/563629, 2015.

Yevjevich, V.: An objective approach to definitions and investigations of continental hydrologic droughts, Hydrology papers, Colorado State University, Fort Collins, Colorado, 23, 18 pp, 1967.

Yue, S., Pilon, P., Phinney, B., and Cavadias G.: The influence of autocorrelation on the ability to detect trend in hydrology series, Hydrol. Proc., 16, 1807-1829, 2002.

Yue, S. and Wang, C.: The Mann-Kendall test modified by effective sample size to detect trend in serially correlated hydrological series, Water Resour. Manage., 18, 201-208, https://doi.org/10.1023/B:WARM.0000043140.61082.60, 2004. 